\title{
Plasticity of the RNA kink turn structural motif
}

\author{
ALEXANDRA H. ANTONIOLI, JESSE C. COCHRANE, ${ }^{1}$ SARAH V. LIPCHOCK, and SCOTT A. STROBEL
}

Department of Molecular Biophysics and Biochemistry, Yale University, New Haven, Connecticut 06520-8114, USA

\begin{abstract}
The kink turn (K-turn) is an RNA structural motif found in many biologically significant RNAs. While most examples of the K-turn have a similar fold, the crystal structure of the Azoarcus group I intron revealed a novel RNA conformation, a reverse kink turn bent in the direction opposite that of a consensus K-turn. The reverse K-turn is bent toward the major grooves rather than the minor grooves of the flanking helices, yet the sequence differs from the K-turn consensus by only a single nucleotide. Here we demonstrate that the reverse bend direction is not solely defined by internal sequence elements, but is instead affected by structural elements external to the K-turn. It bends toward the major groove under the direction of a tetraloop-tetraloop receptor. The ability of one sequence to form two distinct structures demonstrates the inherent plasticity of the K-turn sequence. Such plasticity suggests that the K-turn is not a primary element in RNA folding, but instead is shaped by other structural elements within the RNA or ribonucleoprotein assembly.
\end{abstract}

Keywords: RNA structure; X-ray crystallography; group I intron; reverse kink turn

\section{INTRODUCTION}

Analysis of structural elements that provide stability to global RNA complexes is important for understanding the rules of RNA folding. The kink turn (K-turn) is a wellstudied RNA motif that forms both structured and flexible conformations within larger RNA molecules (Matsumura et al. 2003). The plasticity of the K-turn motif and the ability to analyze its properties at an atomic level make it a good model for studying RNA structure (Turner et al. 2005).

The K-turn was first described in the large ribosomal subunit of Haloarcula marismortui (Klein et al. 2001). Six examples of this motif are present within the H. marismortui $50 \mathrm{~S}$ subunit, and two are present in the Thermus thermophilus 30S subunit (Ban et al. 2000; Schluenzen et al. 2000; Wimberly et al. 2000). Other K-turns are located in nonribosomal structures such as riboswitches, small nucleolar RNAs, and ribozymes (Nottrott et al. 1999; Adams et al. 2004; Montange and Batey 2006; Blouin and Lafontaine 2007). The K-turn is composed of 15 nucleotides (nt) that form a helix-internal-loop-helix structure in duplex RNA

\footnotetext{
${ }^{1}$ Present address: Department of Molecular Biology, Massachusetts General Hospital, and Department of Genetics, Harvard Medical School, 185 Cambridge Street, Boston, MA 02114, USA.

Reprint requests to: Scott A. Strobel, Department of Molecular Biophysics and Biochemistry, Yale University, New Haven, CT 06520-8114, USA; e-mail: scott.strobel@yale.edu; fax: (203) 432-5767.

Article published online ahead of print. Article and publication date are at http://www.rnajournal.org/cgi/doi/10.1261/rna.1883810.
}

(Fig. 1). Ten of these 15 nt make up the K-turn's consensus secondary structure (Klein et al. 2001). A standard K-turn has a canonical helix (C-stem), formed from $\mathrm{C}-\mathrm{G}$ pairs, followed by a 3-nt, asymmetric internal loop that ends with a noncanonical helix (NC-stem) of G.A mispairs. Tertiary interactions to the two closing G.A mispairs facilitate the K-turn bend and include a stabilizing A-minor motif contact to the $\mathrm{A}$ in the first G.A pair. The three nucleotides within the asymmetric loop create the kink in the phosphodiester backbone of the RNA. Nearly every K-turn adheres to the consensus secondary structure and forms a $120^{\circ}$ bend in the helix toward the minor groove (Klein et al. 2001).

Unlike other K-turns, the crystal structure of the Azoarcus group I intron revealed a helix-loop-helix element that has many secondary structural features of a consensus K-turn, yet it is bent in the opposite direction (Adams et al. 2004). Similar to the consensus K-turn, the reverse K-turn has a 3-nt asymmetric bulge and is flanked on both sides by C- and NC-stems. A $90^{\circ}$ bend forms at the asymmetric loop between the P9.0 and P9. The only difference in sequence between the K-turn consensus and that of the reverse K-turn is a G-to-A change (nucleotide 201, Azoarcus numbering) in the first base pair of the NC-stem, resulting in an A.A instead of a G.A mispair. In a standard K-turn, the $5^{\prime}$-most nucleotide of the loop stacks on the C-stem, allowing the second nucleotide in the bulge to stack on the NC-stem, and the third nucleotide to be displaced into solution. In the reverse K-turn, all three residues stack beneath either the $\mathrm{C}$ - or NC-stem with no residue extended into solution. 
A

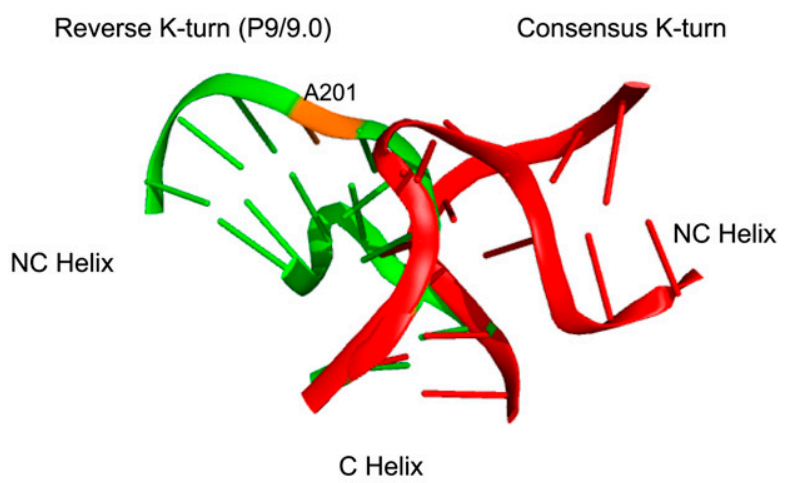

B

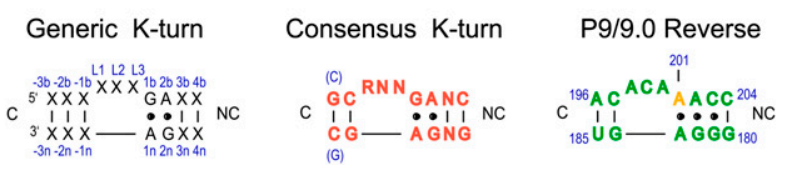

FIGURE 1. (A) Reverse K-turn bent toward the major grooves (green) and consensus K-turn bent toward the minor grooves (red) with position A201 of the Azoarcus intron highlighted in orange. (B) Generic K-turn numbering system (black) as compared with consensus (red) and reverse K-turns (green) with position A201 highlighted in orange.

The absence of the A-minor interaction normally present in consensus K-turns suggests that the tertiary elements that stabilize the reverse K-turn differ from those that stabilize a standard K-turn. In the reverse K-turn a hydrogen bond is observed between the Hoogsteen edge of the middle unpaired residue (C199) and a nonbridging phosphate oxygen of the NC-stem backbone. $\mathrm{A} \mathrm{Mg}^{2+}$ ion may aid in the alignment of the NC-stem phosphate backbone against the C-stem major groove (Strobel et al. 2004).

Given that two similar sequences bend in opposite directions, it raises these questions: Is the bend direction of the reverse K-turn dictated by sequence, tertiary structure interactions, or a combination of both? Is the single change from a $\mathrm{G}$ to an $\mathrm{A}$ at position 201 responsible for the change in bend direction? Or does it result from a specific sequence combination within the asymmetric bulge? Studies of $\mathrm{K}$-turns, such as the well-studied ribosomal Kt-7, indicate that the two conserved G.A mispairs of the NC helix and the hydrogen-bonding interactions they make are critical for the correct folding and stabilization of a standard K-turn (Liu and Lilley 2007; Turner and Lilley 2008). It may be possible that the reverse K-turn has different internal sequence requirements that specify its alternate conformation.

If sequence is insufficient to specify K-turn direction, what other factors and tertiary interactions are responsible for directing the bend of the K-turn toward the major grooves? Many K-turns serve as protein recognition elements (Klein et al. 2001; Brodersen et al. 2002). Binding of proteins, such as the $15.5 \mathrm{~K}$ protein to box $\mathrm{C} / \mathrm{D}$ snoRNA, can influence whether a K-turn remains a flexible loop or becomes locked into a more rigid conformation (Cojocaru et al. 2005; Szewczak et al. 2005). Within the group I intron, a tetraloop-tetraloop receptor (TL-TLR) interaction has been shown to be energetically favorable for stabilization and folding (Rangan et al. 2003). Could this tertiary element play a defining role in K-turn bend direction? In this scenario, the reverse K-turn would serve only as a flexible hinge that is directed toward the major groove by the TL-TLR interaction.

Using biochemical techniques and crystallographic analysis, we determined if mutation of the wild-type reverse $\mathrm{K}$-turn sequence to a consensus K-turn sequence produces a change in bend direction. We further examined the role of both internal and external sequence elements to specify the bend direction of the Azoarcus group I intron K-turn. The data suggest that the K-turn is a malleable element of RNA structure such that two distinct subclasses of tertiary structure can be derived from a single primary nucleic acid sequence.

\section{RESULTS}

We explored the sequence requirements of the reverse kink turn using both kinetic and structural analysis. All studies were performed on the asymmetric loop in the P9.0 helix within the Azoarcus group I intron. We measured splicing rates using the ribozyme form of the Azoarcus intron that catalyzes the attack of the $3^{\prime}$-hydroxyl of exogenous GMP on the oligonucleotide substrate CAUAAA (Fig. 2A). A construct in which P9.0 is fully base-paired (eliminating the asymmetric loop and noncanonical pairings) was developed to ascertain the effect of complete disruption of the reverse $\mathrm{K}$-turn and consequent tertiary interactions such as the docking of the TL in its receptor (Fig. 2C). However, under standard reaction conditions, there was less than a fourfold rate difference between wild-type (WT) and the fully base-paired RNA (BP). This small effect was anticipated because P9.0 is a peripheral element and not explicitly required for splicing activity. In order to highlight the role of P9.0 folding in splicing, we included $1 \mathrm{M}$ urea in the reaction condition, which resulted in greater than a 100-fold rate difference between the WT and the BP ribozymes (Fig. 3). This amount of denaturant has a marginal effect on the wild-type ribozyme, which remains competent for splicing in $5 \mathrm{M}$ urea and retains some activity even in 7.5 M urea (Tanner and Cech 1996). The inclusion of $1 \mathrm{M}$ urea in the reaction buffer provided a simple system to assay the effects of P9.0 mutations on bend direction and flexibility.

\section{Mutation to the consensus K-turn sequence}

The only difference between the reverse K-turn sequence and the consensus $\mathrm{K}$-turn sequence is a single nucleotide in 
A

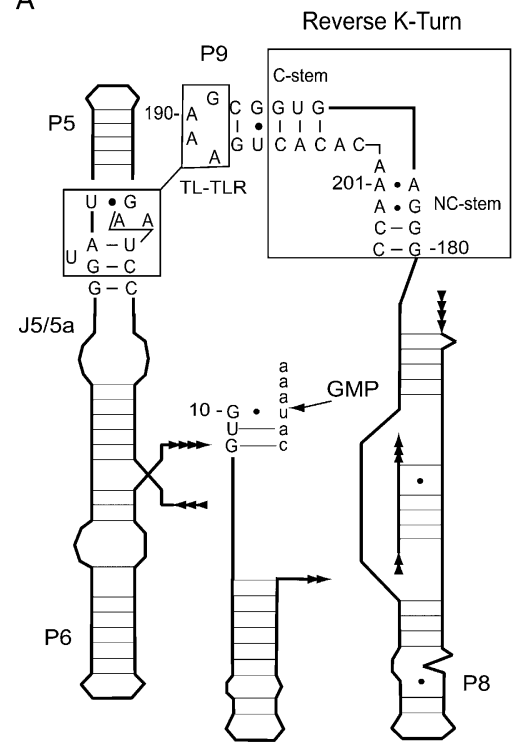

Base-Paired

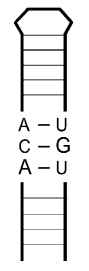

FIGURE 2. (A) Schematic representation of the Azoarcus group I intron used in kinetic assays. The reverse K-turn sequence (boxed region) differs from a consensus K-turn at position A201. A TL-TLR interaction forms between P9 and J5/5a. Exogenous GMP is added in trans, and cleavage of the $5^{\prime}$ exon (represented by CAUAAA) is used to measure splicing activity. (B) Consensus K-turn sequence with G201. (C) Secondary structure of the base-paired construct.

the NC-stem; an A in the reverse K-turn is a $\mathrm{G}$ in the canonical sequence. We compared the activity of the WT ribozyme with one in which the sequence was mutated to that of a consensus K-turn (KT ribozyme with an A201G mutation) under the slightly destabilizing reaction conditions described above. The WT ribozyme reacted with a rate of $39 \times 10^{-3} \mathrm{~min}^{-1}$, while the KT ribozyme was negligibly slower, reacting at a rate of $33 \times 10^{-3} \mathrm{~min}^{-1}$ (Table 1). This suggests that the intron remains properly folded with P9.0 bent toward the major groove despite containing a consensus K-turn sequence that would be predicted to bend in the opposite direction.

\section{Mutations within the internal asymmetric loop}

The three nucleotides (residues 198-200) in the asymmetric loop of a standard K-turn do not display any sequence conservation and are not expected to be defining elements for the consensus K-turn. To determine if these nucleotides define an obligate reverse K-turn subclass, we mutated the nucleotides in the asymmetric loop. Of particular interest is nucleotide C199, which appears to form a hydrogen bond with the phosphate of G180 in the NC-stem. This interaction could facilitate the close stacking of bases under the C- or NC-helix, helping to stabilize the reverse K-turn bend. Constructs $\mathrm{WT}_{\mathrm{C} 199 \mathrm{U}}$ and $\mathrm{KT}_{\mathrm{C} 199 \mathrm{U}}$ disrupt this potential hydrogen bond in the WT and KT backgrounds, respectively. However, the C199U mutation had a small effect on the rate in either context (Table 1). These data suggest that the internal hydrogen-bonding interaction plays at most only a minor role in stabilizing the conformation of the reverse K-turn and is not the defining element for the bend direction.

The asymmetric loop of the reverse K-turn is a relatively A-rich region with adenosines at the first and third nucleotides. Four additional constructs were developed to disrupt the two other positions in the asymmetric loop (constructs $\mathrm{WT}_{\mathrm{A} 198 \mathrm{U}},\left(\mathrm{KT}_{\mathrm{A} 198 \mathrm{U}}, \mathrm{WT}_{\mathrm{A} 200 \mathrm{U}}\right.$, and $\mathrm{KT}_{\mathrm{A} 200 \mathrm{U}}$ mutate the adenosines at positions 198 and 200 in both the WT and KT backgrounds). For all constructs, the rates are within twofold of the wild-type values. These data further suggest that the three nucleotides in the asymmetric loop, the primary site of the bend, are not a significant determinant of K-turn bend direction. The sequence of the Azoarcus group I intron asymmetric loop does not define a reverse K-turn subclass.

\section{Mutation of external elements}

Given that sequence elements within the reverse K-turn do not appear to define bend direction, we next explored the role of external structural factors. We were particularly interested in the possibility that a TL-TLR interaction would have a strong influence on the reverse K-turn bend direction. The tetraloop at the end of P9 interacts with a tetraloop receptor within P5 of this intron (Fig. 2A). We mutated this GAAA tetraloop to UUGG in both the WT and $\mathrm{KT}$ backgrounds ( $\mathrm{WT}_{\mathrm{UUGG}}$ and $\mathrm{KT}_{\mathrm{UUGG}}$ ). This resulted in 740- and 925-fold losses in the rate of cleavage for the two constructs. We also examined a more conservative mutation of the tetraloop, A190C, which changes the GAAA tetraloop to GCAA. The result is a stable GNRA tetraloop, but the tetraloop forms a significantly less stable interaction with the receptor (Costa and Michel 1997; Murphy and Cech 1993). We found a moderate fivefold

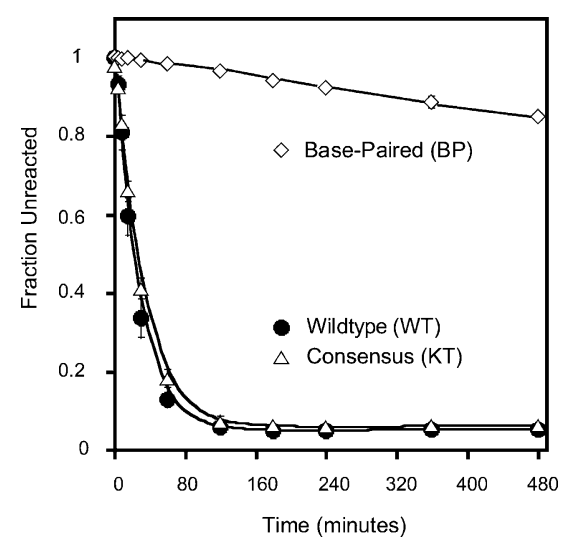

FIGURE 3. Reaction rates for wild-type (WT), consensus (KT), and base-paired (BP) Azoarcus constructs. The fraction of uncleaved substrate is plotted as a function of time with final rates determined by fitting the curves to a first-order rate equation. 
TABLE 1. First-order rate kinetics for Azoarcus group I intron mutants

\begin{tabular}{|c|c|c|c|}
\hline Mutant & Location of mutation & $\begin{array}{c}k_{\text {obs }} \\
{\left[\left(10^{-3}\right) \mathrm{min}^{-1}\right]}\end{array}$ & $\begin{array}{c}\text { Relative } \\
\text { rate decrease }\end{array}$ \\
\hline WT & - & $37 \pm 3.0$ & 1.0 \\
\hline KT & A201G & $33 \pm 2.7$ & 1.2 \\
\hline BP & Base-pairing nucleotides 198-200 & $0.3 \pm 0.09$ & 123 \\
\hline WT $_{\mathrm{C} 199 \mathrm{U}}$ & C199U & $41 \pm 3.2$ & 1.0 \\
\hline $\mathrm{KT}_{\mathrm{C} 199 \mathrm{U}}$ & C199U, A201G & $22 \pm 3.0$ & 1.7 \\
\hline $\mathrm{WT}_{\mathrm{A} 200 \mathrm{U}}$ & A200U & $35 \pm 1.0$ & 1.1 \\
\hline $\mathrm{KT}_{\mathrm{A} 200 \mathrm{U}}$ & A200U, A201G & $26 \pm 0.8$ & 1.4 \\
\hline $\mathrm{WT}_{\mathrm{A} 198 \mathrm{U}}$ & A198U & $15 \pm 1.0$ & 2.4 \\
\hline $\mathrm{KT}_{\mathrm{A} 198 \mathrm{U}}$ & A198U, A201G & $16 \pm 0.5$ & 2.3 \\
\hline WT UUGG & G189U, A190U, A191G, A192G & $0.05 \pm 0.02$ & 740 \\
\hline KT UUGG & G189U, A190U, A191G, A192G, A201G & $0.04 \pm 0.03$ & 925 \\
\hline $\mathrm{WT}_{\mathrm{A} 190 \mathrm{C}}$ & A190C & $7.3 \pm 0.6$ & 5 \\
\hline $\mathrm{KT}_{\mathrm{A} 190 \mathrm{C}}$ & A190C, A201G & $1.4 \pm 0.7$ & 26 \\
\hline
\end{tabular}

Mutations were made to internal and external positions within the P9/P9.0 helix.

rate effect in the wild-type background ( $\left.\mathrm{WT}_{\mathrm{A} 190 \mathrm{C}}\right)$, but an almost 30-fold effect for the RNA with mutations in both external and internal regions $\left(\mathrm{KT}_{\mathrm{A} 190 \mathrm{C}}\right)$. The combination of internal and external mutations appears to destabilize the intron more than either point mutation alone.

\section{Structure determination of the consensus sequence}

To confirm that we made the proper structural interpretation of this kinetic result, we crystallized the A201G mutant RNA (KT) and obtained the structure by molecular replacement. The construct was assembled in a manner similar to that used to obtain the original Azoarcus group I intron crystal structure (Adams et al. 2004). A 22-residue oligonucleotide, dcircm, which represented the $3^{\prime}$-exon and the $3^{\prime}$-end of the intron and included the A201G point mutation, was crystallized with the $5^{\prime}$-exon CAT and the remainder of the intron produced as an RNA transcript. We obtained a $4.2 \AA$ resolution structure of the mutant group I intron in the same space group $\left(\mathrm{P}_{1} 22\right)$ as previously reported for other Azoarcus intron structures (Table 2; Adams et al. 2004; Stahley and Strobel 2005; Lipchock and Strobel 2008). Both the mutant and the original structures have the same overall architecture (Fig. 4). Although the resolution was limited, there was no observable change in conformation of the phosphate backbone of the P9 helix resulting from the point mutation. Thus, despite a consensus sequence, the P9.0 helix remained bent toward the major grooves. This provides structural support to the kinetic data and suggests that a consensus K-turn sequence can fold in the opposite direction within the context of the Azoarcus ribozyme.

\section{DISCUSSION}

This study demonstrates that the K-turn motif is an example of a plastic secondary structural element that can adopt multiple conformations in the presence of different external factors. We explored the sequence and structural determinants of the reverse K-turn within the context of the Azoarcus ribozyme and found that docking of a TL-TLR can mold a consensus K-turn into an unusual bend direction. The ability of the K-turn to form two distinct, yet stable structures from the same primary sequence supports the proposal that K-turns are not principal organizing elements of RNA structure (Goody et al. 2004; Turner et al. 2005). While other internal loop motifs, such as the bulged$\mathrm{G}$ motif, are defined as rigid regions (Correll et al. 2003), K-turns are dynamic with kinked and unkinked conformations influenced by metal ion concentration, tertiary

TABLE 2. Crystallographic data collection and refinement statistics

\begin{tabular}{ll}
\hline Parameter & \multicolumn{1}{c}{ Result } \\
\hline $\begin{array}{l}\text { Data Collection } \\
\text { Cell dimensions }\end{array}$ & \\
$\quad a=b(\AA)$ & 109.8 \\
$\quad c(\AA)$ & 250.2 \\
$\alpha=\beta=\gamma\left({ }^{\circ}\right)$ & 90 \\
Wavelength $(\AA)$ & 0.9783 \\
Resolution $(\AA)^{\mathrm{a}}$ & $50.0-4.2(4.4-4.2)$ \\
$R_{\text {merge }}(\%)^{\mathrm{a}}$ & $10.1(78.9)$ \\
$<\mid>/<\sigma(\mid)>^{\mathrm{a}}$ & $15.5(2.2)$ \\
Completeness $(\%)^{\mathrm{a}}$ & $99.4(100)$ \\
Redundancy & $6.3(6.4)$ \\
Refinement & \\
Resolution $(\AA)$ & $50.0-4.2$ \\
Number of Reflections ${ }^{\mathrm{b}}$ & $11,715(562)$ \\
$R_{\text {work }} / R_{\text {free }}(\%)$ & $25.7 / 30.3$ \\
RMSD bond $(\AA)$ & 0.009 \\
RMSD angle $\left({ }^{\circ}\right)$ & 1.806 \\
Protein database accession code & $311 \mathrm{~N}$ \\
\hline
\end{tabular}

${ }^{a}$ Values in parentheses are for the highest-resolution shell.

balues in parentheses are for the cross-validation test set. 


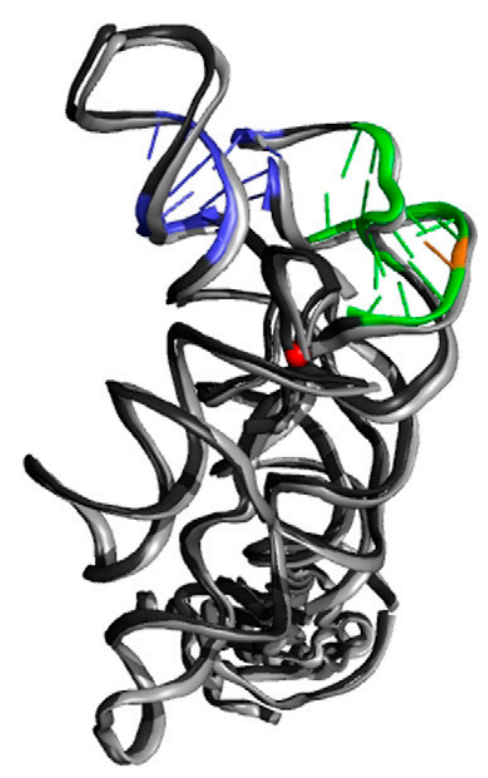

FIGURE 4. Comparison of a crystal structure of an Azoarcus mutant with a consensus K-turn sequence (green/orange) to the original Azoarcus intron structure (gray). The P9-J5/5a tetraloop-tetraloop receptor interaction is highlighted (blue) as well as a scissile phosphate in the intron core (red).

interactions, and protein binding (Nottrott et al. 1999; Goody et al. 2004).

\section{A tetraloop-tetraloop receptor interaction stabilizes the reverse K-turn bend direction}

Solution studies of isolated K-turn motifs show flexible RNAs that are able to form tightly kinked or extended conformations in the presence or absence of metal ions (Goody et al. 2004). Other K-turns, like many in the ribosome, rely on external ligands and tertiary interactions to mold their conformations (Matsumura et al. 2003). Because K-turns can be shaped by external elements we investigated the role of the TL-TLR interaction between P5 and $\mathrm{P} 9$ in the bend direction of the reverse K-turn sequence. We observed that the disrupted tetraloop mutants had the most significant impact on reaction rate, which is consistent with the conclusion that mutations to the GAAA tetraloop of L9 disrupted proper intron folding (Rangan et al. 2003). In fact, it was only when this interaction was lost that we were able to observe any effect from mutation of the reverse $\mathrm{K}$-turn to the consensus sequence.

This view of the K-turn is similar to the bent sequence within the P4-P6 domain of the Tetrahymena group I intron, which also requires external tertiary interactions in order to adopt a bend (Cate et al. 1996a,b). The P4-P6 domain consists of 160 nucleotides and forms an independent tertiary structure including a $180^{\circ}$ hinge at J5/5a (Szewczak and Cech 1997; Cate et al. 1996a,b). To fold correctly, the motif requires a TL-TLR and A-minor motif interactions. The nucleotide sequence that makes up the J5/5a hinge has only a minor role in specifying folding (Szewczak and Cech 1997). Similar to the J5/5a hinge, we found that the reverse K-turn loop nucleotides do not direct folding of the K-turn in the Azoarcus group I intron; instead, a TL-TLR interaction is the main determinant of the reverse K-turn bending, and the reverse K-turn is simply a flexible region that can be molded into a major groove bend.

In the hierarchy of RNA folding, a TL-TLR has a dominant role in structure stabilization relative to the KT-bend direction. The plasticity of the reverse K-turn enables it to be shaped in different conformations using distal tertiary contacts and protein binding. While it is certainly possible to design RNA to have a K-turn bend, the actual direction of that bend may be more difficult to predict suggesting that the knowledge of structural plasticity for an RNA secondary structure could enhance RNA tertiary structure prediction.

\section{MATERIALS AND METHODS}

\section{Assembly of kinetic assay constructs}

The WT reverse sequence template consisted of an Azoarcus group I intron construct (L-6 C204) that terminated at nucleotide position C204. Twelve additional constructs used in kinetic experiments were generated using site-directed mutagenesis (QuikChange, Stratagene) with the WT construct serving as template DNA (Table 1).

\section{In vitro transcription}

DNA was prepared for in vitro transcription by performing an EarI restriction enzyme digestion. RNA was transcribed using T7 RNA polymerase and purified by electrophoresis in a $6 \%$ polyacrylamide gel containing $7 \mathrm{M}$ urea. Following an overnight elution step in water, the RNAs were concentrated to $0.1-1 \mathrm{mg} / \mathrm{mL}$ using Amicon Centrifugal Filter devices.

\section{Short oligonucleotide radiolabeling}

A small oligonucleotide was $5^{\prime}$-end-radiolabeled in a $10-\mu \mathrm{L}$ reaction with $\left[\gamma^{-}{ }^{32} \mathrm{P}\right]$ ATP using T4 PNK. Reagents were incubated for $1 \mathrm{~h}$ at $37^{\circ} \mathrm{C}$ and quenched by the addition of formamide loading buffer (95\% formamide, $2.5 \mathrm{mM}$ EDTA, 0.1\% bromophenol blue, and $0.1 \%$ xylene cyanol). The labeled oligonucleotide was purified by $20 \%$ non-denaturing PAGE, and the labeled oligonucleotide was eluted overnight in water.

\section{Kinetic measurements}

Kinetic reactions were performed to measure the rate of splicing activity for each construct. Reactions contained $3 \mu \mathrm{M}$ RNA, $1 \times$ kinetic buffer $\left[3 \mathrm{mM} \mathrm{MgCl}_{2}, 25 \mathrm{mM}\right.$ MES at $\mathrm{pH} 6.0$, and $1 \mathrm{mM}$ $\mathrm{Mn}(\mathrm{OAc})_{2}$ ], $5 \mathrm{mM}$ exogenous guanosine monophosphate (GMP), $1 \mathrm{M}$ urea, and trace amounts of ${ }^{32} \mathrm{P}$-radiolabeled CAUAAA. Reaction mixtures were preincubated for $2 \mathrm{~min}$ at $50^{\circ} \mathrm{C}$ before the addition of labeled oligonucleotide and exogenous GMP. Time points were taken by removing $2 \mu \mathrm{L}$ of the reaction mixture and quenching with $8 \mu \mathrm{L}$ of formamide loading buffer. A $20 \%$ 
denaturing polyacrylamide gel was used to separate the unligated substrates from the ligated products. RNA fragments were visualized using a Storm PhosphorImager (GE Healthcare), and data were quantized using ImageQuant (GE Healthcare). For each construct, a reaction rate was found by plotting the fraction of unligated product versus time and fitting the data with KaleidaGraph to an exponential decay endpoint using Equation 1:

$$
f_{\text {unreact }}=\left(1-F_{\text {unreact }}\right) * \exp \left(-k_{\text {obs }} * t\right)+f_{\text {unreact }},
$$

where $f_{\text {unreact }}=$ fraction unreacted; $F_{\text {unreact }}=$ fraction unreactive.

\section{Crystallization construct assembly and structure determination}

A single crystallization construct was assembled from an RNA transcript (UP62) and two synthetic oligonucleotides (CAT and dcircm; Dharmacon). The oligonucleotide, dcircm, represents the $3^{\prime}$-end of the intron and the $3^{\prime}$ exon. It contains a $G$ at position 201 , instead of $A$, to create the KT sequence, and a deoxyG at position 206. Oligonucleotides were deprotected according to the manufacturer's protocol. The UP62 RNA $(120 \mu \mathrm{M})$ and dcircm $(150 \mu \mathrm{M})$ were combined and heated for $2 \mathrm{~min}$ to $50^{\circ} \mathrm{C}$ in $10 \mathrm{mM}$ sodium cacodylate $(\mathrm{pH} 6.5)$ and $15 \mathrm{mM} \mathrm{Mg}(\mathrm{OAc})_{2}$. After slow cooling for $15 \mathrm{~min}$, CAT $(150 \mu \mathrm{M})$ and the RNA binding domain of the U1A protein $(140 \mu \mathrm{M})$ were added. Hanging drop crystallization trials were performed as described previously (Adams et al. 2004). After $3 \mathrm{~h}$, streak seeding was performed using crystals containing an unmutated oligonucleotide. The average crystal size was $120 \mu \mathrm{m} \times 100 \mu \mathrm{m} \times 100 \mu \mathrm{m}$, and crystals typically appeared $12 \mathrm{~h}$ after seeding. Crystals were stabilized in 30\% MPD, $50 \mathrm{mM}$ sodium cacodylate ( $\mathrm{pH} 6.8), 10 \mathrm{mM} \mathrm{Mg}(\mathrm{OAc})_{2}, 10 \mathrm{mM} \mathrm{KOAc}$, and $0.2 \mathrm{mM} \mathrm{Co}\left(\mathrm{NH}_{3}\right)_{6}{ }^{3+}$; and were flash frozen in liquid nitrogen.

Diffraction data were indexed and scaled using HKL2000, and the Azoarcus deoxy pre-2S group I intron structure (PDB ID $1 \mathrm{U6B}$ ) was used to perform molecular replacement to generate a model of the mutant RNA (Otwinoski and Minor 1997; Adams et al. 2004). As previously reported, this construct yielded crystals of space group $\mathrm{P} 4_{1} 22$. Modeling and rigid body refinement of the structure was performed with COOT and REFMAC5 (Winn et al. 2001; Emsley and Cowtan 2004).

\section{Protein Data Bank entry}

Atomic coordinates and structure factors have been deposited in the Protein Data Bank, http://www.rcsb.org, under PDB ID 3IIN.

\section{ACKNOWLEDGMENTS}

We thank the Beamline staff at the National Synchrotron Light Sourc (NSLS) for assistance with X-ray data collection. This work was supported by NIH PO1 grant GM022778 to S.A.S.

Received August 17, 2009; accepted December 9, 2009.

\section{REFERENCES}

Adams PL, Stahley MR, Gill ML, Kosek AB, Wang J, Strobel SA. 2004. Crystal structure of a group I intron splicing intermediate. RNA 10: $1867-1887$.
Ban N, Nissen P, Hansen J, Moore PB, Steitz TA. 2000. The complete atomic structure of the large ribosomal subunit at $2.4 \AA$ resolution. Science 289: 905-920.

Blouin S, Lafontaine DA. 2007. A loop-loop interaction and a K-turn motif located in the lysine aptamer domain are important for the riboswitch gene regulation control. RNA 13: 1256-1267.

Brodersen DE, Clemons WM Jr, Carter AP, Wimberly BT, Ramakrishnan V. 2002. Crystal structure of the $30 \mathrm{~S}$ ribosomal subunit from Thermus thermophilus: Structure of the proteins and their interactions with 16 S RNA. J Mol Biol 316: 725-768.

Cate JH, Gooding AR, Podell E, Zhou K, Golden BL, Kundrot CE, Cech TR, Doudna JA. 1996a. Crystal structure of a group I ribozyme domain: Principles of RNA packing. Science 273: $1678-1685$.

Cate JH, Gooding AR, Podell E, Zhou K, Golden BL, Szewczak AA, Kundrot CE, Cech TR, Doudna JA. 1996b. RNA tertiary structure mediation by adenosine platforms. Science 273: 16961699.

Cojocaru V, Nottrott S, Klement R, Jovin TM. 2005. The snRNP $15.5 \mathrm{~K}$ protein folds its cognate K-turn RNA: A combined theoretical and biochemical study. RNA 11: 197-209.

Correll CC, Beneken J, Plantinga MJ, Lubbers M, Chan YL. 2003. The common and the distinctive features of the bulged-G motif based on a $1.04 \AA$ resolution RNA structure. Nucleic Acids Res 31: 68066818.

Costa M, Michel F. 1997. Rules for RNA recognition of GNRA tetraloops deduced by in vitro selection: Comparison with in vivo evolution. Embo J 16: 3289-3302.

Emsley P, Cowtan K. 2004. Coot: Model-building tools for molecular graphics. Acta Crystallogr D Biol Crystallogr 60: 2126-2132.

Goody TA, Melcher SE, Norman DG, Lilley DM. 2004. The kink-turn motif in RNA is dimorphic, and metal ion-dependent. RNA 10: 254-264.

Klein DJ, Schmeing TM, Moore PB, Steitz TA. 2001. The kink-turn: A new RNA secondary structure motif. EMBO J 20: 4214-4221.

Lipchock SV, Strobel SA. 2008. A relaxed active site after exon ligation by the group I intron. Proc Natl Acad Sci 105: 56995704.

Liu J, Lilley DM. 2007. The role of specific 2'-hydroxyl groups in the stabilization of the folded conformation of kink-turn RNA. RNA 13: $200-210$.

Matsumura S, Ikawa Y, Inoue T. 2003. Biochemical characterization of the kink-turn RNA motif. Nucleic Acids Res 31: 5544-5551.

Montange RK, Batey RT. 2006. Structure of the S-adenosylmethionine riboswitch regulatory mRNA element. Nature 441: 1172-1175.

Murphy FL, Cech TR. 1993. An independently folding domain of RNA tertiary structure within the Tetrahymena ribozyme. Biochemistry 32: 5291-5300.

Nottrott S, Hartmuth K, Fabrizio P, Urlaub H, Vidovic I, Ficner R, Luhrmann R. 1999. Functional interaction of a novel 15.5kD [U4/ U6.U5] tri-snRNP protein with the 5' stem-loop of U4 snRNA. EMBO J 18: 6119-6133.

Otwinoski Z, Minor W. 1997. Processing of X-ray diffraction data collected in oscillation mode. In Methods in enzymology (ed. JN Abelson et al.), Vol. 276, pp. 307-326. Academic Press, New York.

Rangan P, Masquida B, Westhof E, Woodson SA. 2003. Assembly of core helices and rapid tertiary folding of a small bacterial group I ribozyme. Proc Natl Acad Sci 100: 1574-1579.

Schluenzen F, Tocilj A, Zarivach R, Harms J, Gluehmann M, Janell D, Bashan A, Bartels H, Agmon I, Franceschi F, et al. 2000. Structure of functionally activated small ribosomal subunit at $3.3 \AA$ resolution. Cell 102: 615-623.

Stahley MR, Strobel SA. 2005. Structural evidence for a two-metal-ion mechanism of group I intron splicing. Science 309: 1587-1590.

Strobel SA, Adams PL, Stahley MR, Wang J. 2004. RNA kink turns to the left and to the right. RNA 10: 1852-1854.

Szewczak AA, Cech TR. 1997. An RNA internal loop acts as a hinge to facilitate ribozyme folding and catalysis. RNA 3: 838-849. 
Szewczak LB, Gabrielsen JS, DeGregorio SJ, Strobel SA, Steitz JA. 2005. Molecular basis for RNA kink-turn recognition by the h15.5K small RNP protein. RNA 11: 1407-1419.

Tanner MA, Cech TR. 1996. Activity and thermostability of the small self-splicing group I intron in the pre-tRNA ${ }^{\text {Ile }}$ of the purple bacterium Azoarcus. RNA 2: 74-83.

Turner B, Lilley DM. 2008. The importance of G.A hydrogen bonding in the metal ion- and protein-induced folding of a kink turn RNA. J Mol Biol 381: 431-442.
Turner B, Melcher SE, Wilson TJ, Norman DG, Lilley DM. 2005. Induced fit of RNA on binding the L7Ae protein to the kink-turn motif. RNA 11: 1192-1200.

Wimberly BT, Brodersen DE, Clemons WM Jr, Morgan-Warren RJ, Carter AP, Vonrhein C, Hartsch T, Ramakrishnan V. 2000. Structure of the 30S ribosomal subunit. Nature 407: 327-339.

Winn MD, Isupov MN, Murshudov GN. 2001. Use of TLS parameters to model anisotropic displacements in macromolecular refinement. Acta Crystallogr D Biol Crystallogr 57: 122-133. 

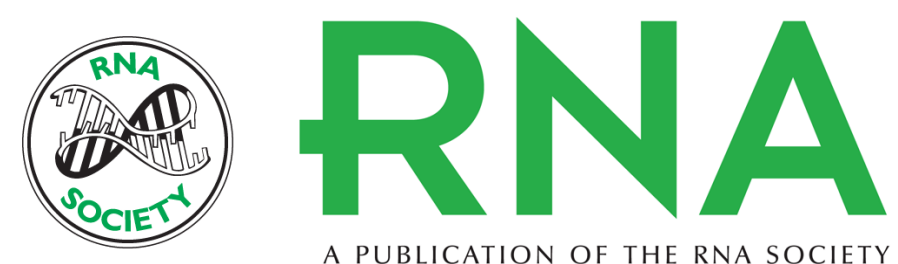

A PUBLICATION OF THE RNA SOCIETY

\title{
Plasticity of the RNA kink turn structural motif
}

\author{
Alexandra H. Antonioli, Jesse C. Cochrane, Sarah V. Lipchock, et al.
}

RNA 2010 16: 762-768 originally published online February 9, 2010

Access the most recent version at doi:10.1261/rna.1883810

\section{References This article cites 30 articles, 19 of which can be accessed free at: http://rnajournal.cshlp.org/content/16/4/762.full.html\#ref-list-1}

\section{License}

Email Alerting Receive free email alerts when new articles cite this article - sign up in the box at the Service top right corner of the article or click here. 